УДК $378.011 .3-051: 82-4: 316.62$

DOI:

Тетяна Опалюк, кандидат педагогічних наук, асистент кафедри соціальної педагогіки і соціальної роботи Кам'янець-Подільського національного університету імені Івана Огієнка

\title{
РОЛЬ СОЦІО-ДИДАКТИЧНОГО СЕРЕДОВИЩА У ПІДГОТОВЦ МАЙБУТНІХ УЧИТЕЛІВ ДО НАПИСАННЯ ЕСЕ НА СОЦАЛЬНО ЗНАЧУЩУ ТЕМАТИКУ
}

У статті представлено результати комплексного дослідження сутності, ключових характеристик та ролі соито-дидактичного середовища у підготовиі майбутніх вчителів до написання есе на соиіальну, соиіально-педагогічну тематику. Аналізується науково-методична література з проблем формування освітнього простору, навчального середовищца, позитивного мікроклімату у процесі професійного становлення спеціаліста, особливостей психологічного супроводу навчальної діяльності студентів у його контексті.

Ключові слова: сочуіо-дидактичне середовище; есе; особистісно орієнтована освіта; иулісний освітній простір; освітнє середовище; психологічний мікроклімат.

תim. 7.

Tetyana Opalyuk, Ph.D.(Pedagogy), Assistant of the Social Pedagogy and Social Work Department Kamyanets-Podilskiy Ivan Ohiyenko National University

\section{THE ROLE OF SOCIO-DIDACTIC ENVIRONMENT IN THE FUTURE TEACHERS' PREPARATION FOR THE WRITING OF ESSAY ON THE SOCIALLY SIGNIFICANT TOPICS}

The article presents the results of a comprehensive study of the essence, the key characteristics and the role of the socio-didactic environment in the future teachers' preparation for social and socio-pedagogical thematic essays writing. We analyzed the scientific and methodical literature that reveal the problems of educational space, the educational environment and positive microclimate formation in the process of professional development of a specialist and features of psychological support of educational activity of students in its context. The study of results of research of specified range of issues, as well as the practice of professional education, enables us to identify the functions implemented by the socio-didactic environment. These functions may be the following: unifying and consolidating, motivational and stimulating, emotional and energetic, regulatory and managerial. All of them contribute greatly to the development of the social and pedagogical competence of a teacher, his or her personal, professional and educational self-realization. The role of socio-didactic environment in the future teachers' preparation for socially important topics of essays writing cannot be overestimated because it involves the formation of favorable conditions for creative, personally oriented educational activity of students in the process of mastering the profession, including the formation of socio-pedagogical and socio-reflexive competencies.

The socio-didactic environment is a complex of psychological and emotionally rich form aimed at developing the creative educational activity of students, ensuring the creation of a defined set of didactic conditions adapted to the peculiarities of the implementation of the essay writing method, and, consequently, the development of the social competence of a future teacher in the system of personally oriented professional training.

The article also presents the information on the main points that can be the basis for the development of the socio-didactic environment as a social and psychological support of the students' preparation for the sociopedagogical thematics essays writing, ensuring its effectiveness and guided by the standards of personally oriented professional education.

Keywords: the socio-didactic environment; an essay; personally oriented education; integral educational space; an educational environment; psychological microclimate.

П остановка проблеми. Есе, як самостійна творча робота студента, за своєю суттю $\epsilon$ особистісно орієнтованим і в системі професійної підготовки майбутнього вчителя реалізує функції розвитку творчого мислення, здатності чітко, лаконічно та переконливо формулювати свої думки, використовувати образність, аргументованість мовлення для їх презентації, формування текстів для особистісного, професійного, соціального самовизначення на основі виявлення ціннісносмислових конструктів, причинно-наслідкових зв'язків у контексті проблеми, відповідно до визначеної тематики.

Есе на соціально-педагогічну тематику, як метод навчання, має високий потенціал компетентнісної освіти й реалізується за формулою взаємодії досвідів: формалізованого, 


\section{РОЛЬСОЩІО-ДИДАКТИЧНОГОСЕРЕДОВИЩА У ПІДГОТОВЦІМАЙБУТНІХ УЧИТЕЛІВ ДОНАПИСАННЯ ЕСЕНАСОЦАЛЬНОЗНАЧУЩУ ТЕМАТИКУ}

представленого в рамках навчальних дисциплін (педагогіки, соціології, філософії, психології, інших гуманітарних), і власного, що фіксується в асоціативних зв'язках, пов' язаних із трактуванням теоретичних позицій через призму власних життєвих, соціальних, освітніх реалій.

Виходячи з вищезазначеного, однією 3 важливих умов ефективності навчання, пов'язаного з особистісною спрямованістю трактування теорії та виконання особистісно орієнтованих навчальних завдань (авторське трактування проблеми, озвучення власних суджень і їх аргументації, захист власних проектів, апелювання до життєвого досвіду) потребує сприятливого соціо-дидактичного середовища, яке задавало би психологічний контент для самоактуалізації, самоствердження, самореалізації студента у процесі навчальної діяльності означеного рівня.

Проблеми формування цілісного освітнього простору, освітнього середовища, психологічного мікроклімату стають усе більш актуальними у зв’язку з переходом від інформаційної до особистісно орієнтованої, компетентнісної системи освіти, у тому числі професійної, передовсім, зважаючи на те, що вона базується на основі “Я-концепції”, особистісної самоактуалізації. В умовах інформаційної, знаннєвої системи освіти сприятливий психологічний мікроклімат, особистісно орієнтоване освітнє середовище, як правило, декларується, вони не $\epsilon$ затребувані освітою, що реалізувалася більшою мірою за директивноавторитарною управлінською парадигмою. Компететнісна система освіти - це принципово інший формат навчальної діяльності, оскільки вона спрямована на самореалізацію особистості студента й формується за принципами інтерактивного навчання як взаємодії досвідів того, хто вчить, та того, хто навчається.

Аналіз наукових публікацій. Проблеми впливу соціального, освітнього середовища, психологічного мікроклімату на формування особистості (у тому числі студента, школяра) були предметом досліджень таких вітчизняних і зарубіжних дослідників, якШ. Амонашвілі,О. Антонова, О. Гавриленко, Е. Зєєр, В. Левін, О. Макогон, Н. Романченко, В. Семенов, С. Скидан, В. Слободчиков та ін.

Так, Е. Зєєр професійне становлення визначає як формоутворення особистості, адекватне вимогам професійної діяльності $[1,38]$. Оскільки компонентами професійної спрямованості $є$ : мотиви (наміри, інтереси, схильності, ідеали); ціннісні орієнтації (зміст праці, заробітна плата, добробут, кваліфікація, кар'єра, соціальний стан тощо); професійна позиція (ставлення до професії, установки, очікування й готовність до професійного розвитку); соціально-професійний статус [1], то стає зрозумілим, що емоційноціннісна складова професійної компетентності найбільш ефективно формується в умовах творчої діяльності, яка може бути ефективною виключно за умов іiі позитивного емоційно-психологічного супроводу.

Мета статті - 3'ясування сутності, базових характеристик соціо-дидактичного середовища, а також його функціонального призначення у підготовці майбутніх учителів до написання есе на соціально значущу тематику.

Виклад основного матеріалу. Формування соціальної компетентності майбутнього вчителя в навчальному процесі потребує створення адекватного соціо-дидактичного середовища, яке, $з$ одного боку, забезпечувало б реалізацію соціальної функції навчання, з іншого - формувало б сприятливі умови для творчої діяльності, самореалізації студента в контексті особистісно орієнтованої навчальної діяльності.

Погоджуємося з ідеями С. Скидана стосовно того, що навчальне середовище слід розглядати у двох площинах: зовнішнє (фізичне середовище, що оточує людину) і внутрішнє (яке виховує людину - психологічний клімат, спілкування тощо). А тому, важливою $є$ нерозривність людського чинника та чинників навчального середовища, цілісність системи “викладач студент (аспірант) - навчальне середовище” [4].

Деталізуючи проблему, С. Макагон детермінує сприятливе навчально-виховне середовище як середовище інтегроване, що містить цілу низку різних мікросередовищ: інтелектуальне, психологічне, науково-методичне, соціальне, культурно-естетичне, фізичне, санітарногігієнічне, електронне; кожне з яких має спільні й відмінні ознаки [2, $74-79]$.

В. Слободчиков визначає функціональну спрямованість освітнього середовища як механізму сприяння взаємодії предметності культури суспільства та розвитку особистості: то $\epsilon$ два полюси - предметність культури і внутрішній світ, сутність сили людини - у їх взаємопідтримці в освітньому процесі та задаються межі змісту освітнього середовища і його складу [5].

Аналізуючи різні позиції дослідників стосовно трактування сутності понять, пов'язаних із навчальним середовищем, можна виділити ті, які $\epsilon$ спільними як для вказаних вище авторів, так й інших учених, які займалися проблемами середовища, простору, мікроклімату в освіті. 


\section{РОЛЬСОЦІО-ДИДАКТИЧНОГОСЕРЕДОВИЩА У ПІДГОТОВЦІМАЙБУТНІХ УЧИТЕЛІВ}

ДОНАПИСАННЯ ЕСЕ НАСОЦАЛЬНОЗНАЧУЩУ ТЕМАТИКУ

Зокрема, навчальне середовище вивчається як складно структуроване утворення, яке базується на системі зовнішніх і внутрішніх зв'язків і залежностей, і яке не лише впливає, а й визначає ефективність професійної підготовки спеціаліста. Зазначається, що процес оволодіння професією включає психологічну складову, пов'язану з особистісною спрямованістю, цінностями, ідеалами, інтересами та ін., які в системі знаннсвої освіти майже не актуалізуються, у всякому разі вони не $\epsilon$ іманентною складовою навчання, а тому їх розвиток означений високим рівнем стихійності. Розуміння середовища як механізму “сприяння взаємодії предметності культури суспільства та розвитку особистості" вказує на інтерактивну природу особистісно орієнтованого навчання.

Характеристики сприятливого освітнього, навчального середовища різнорівневі та різноаспектні. Інтегрально Л. Орлова визначає тип сприятливого освітнього середовища безвідносно до конкретної форми діяльності, яке характеризують: довіра, доброзичливість, чуйність, висока взаємовимогливість і ділова критика; вільне висловлювання власної думки під час обговорення питань, ...наявність умов для активної професійної і творчої діяльності, самореалізації, самоствердження, саморозвитку кожного [3].

Адаптуючи вказані позиції до проблеми соціодидактичного забезпечення професійної підготовки майбутнього вчителя, соціодидактичне середовище трактуємо як складноструктуроване спеціально організоване мобільне, адаптивне середовище, спрямоване на забезпечення створення визначеного комплексу дидактичних умов розвитку соціальної компетентності майбутнього вчителя, які реалізують функцію фасилітації (від англ. Facilitate - допомагати, полегшувати, сприяти) у системі особистісно орієнтованого професійного навчання.

У процесі професійної підготовки вчителя особливої значущості набувають інтерактивні, творчі методи навчання, до яких відноситься есе, i які за своєю природою $є$ особистісно орієнтованими (такими, що сприяють взаємодії предметності культури та розвитку особистості), а тому потребують сприятливого середовища, психологічного мікроклімату, оптимальної системи особистісних взаємовідносин суб'єктів освітньої діяльності.

У зв'язку з цим, дослідження проблем психологічного супроводу використання методів творчого, інтерактивного навчання, які пов'язані 3 актуалізацією особистісного, життєвого, соціального просторів студента як суб'єкта навчання, набуває особливої актуальності й закономірно потребують теоретико-практичного обгрунтування алгоритмів і методики формування сприятливих умов, позитивного соціодидактичного середовища як основи навчання, освітнього простору навчального закладу в цілому.

Аналіз досліджень з проблем формування навчального, освітнього, соціального середовища, а також практики професійної освіти вчителя дає змогу говорити про функції, які реалізує соціодидактичне середовище.

Об 'єднувально-консолідувальна функиія як об'єднання студентів навколо виконання спільних соціально спрямованих конкретних навчальних завдань у контексті пріоритетів професійного становлення майбутнього вчителя. У процесі підготовки до написання есе на соціально-педагогічну тематику та його представлення важливо налаштувати студентів на толерантність, інтерес, психологічну підтримку, допомогу та взаємне прийняття різних, часто суперечливих позицій, які є результатом роздумів над проблемами, поєднуючи об'єктивно задані алгоритми роботи над проблемою та досвідний матеріал, який акумулюється в цінностях, ставленнях, особистісних пріоритетах.

Мотиваційно-стимулювальна функиія спонукає, з одного боку, до особистісної, професійно-освітньої самореалізації, з іншого формування спільного навчального “продукту” (як результату консолідації зусиль студентів) у сприятливій психологічній атмосфері. Реальне оволодіння методом есе, який є цінним не лише для ефективного професійного становлення, а й майбутньоїпрофесійної діяльності (учити школярів писати есе), передбачає не одноразовий акт філософських роздумів над заданою проблемою, а довготривалу навчальну роботу, яка стимулює до системної аналітико-рефлексійної діяльності, що виявляється в різних формах навчальної роботи, на різних рівнях її реалізації.

Емоційно-енергетична функиія - сприяє формування загального настрою на співпрацю, творчу навчальну діяльність, пов'язану 3 самоактуалізацією та самореалізацією особистості студента, забезпечення відчуття комфортності в навчанні, зацікавленості у груповій комунікації з проблематики, що представляє спільний інтерес, інших формах взаємодії, що в цілому продукує відчуття колективного успіху, у його контексті - індивідуального успіху кожного студента.

Регулювально-управлінська - передбачає управління не лише ефективністю навчальної діяльності, а й “колективним настроєм" як іiі 


\section{РОЛЬСОЦІ-ДИДАКТИЧНОГОСЕРЕДОВИЩА У ПІДГОТОВЦІМАЙБУТНІХ УЧИТЕЛІВ ДОНАПИСАННЯ ЕСЕНАСОЦІАЛЬНОЗНАЧУЩУ ТЕМАТИКУ}

психологічним супроводом (задоволеність навчанням, стосунками, стилем управління та ін.), що $є$ поліфункціональним і визначає базові умови для самореалізації кожного студента в навчальній діяльності.

Як зазначає К. Шендеровський, “Індивідуалізація сучасних суспільних відносин та, як наслідок, індивідуалізація сучасної професійної освіти відкриті для застосування нових ефективних форм діяльності, у т. ч. навчальної. Ось чому есе (трансформований, адаптований, змінений жанр літератури) набуває все більшої популярності як вид письмової самостійної роботи українського студента, а саме: як твір-міркування невеликого обсягу 3 вільною композицією, що виражає індивідуальні враження, міркування з конкретного питання, проблеми й свідомо не претендує на повноту й вичерпне трактування теми" $[6,7]$.

Оскільки головна мета есе полягає у формуванні самостійного бачення соціально означеної проблеми та ii письмового представлення, використовуючи адекватні засоби особистісного самовираження (суб'єктивність мислення, образність, стиль мовлення), актуальним предметом теоретико-практичного дослідження в зазначеному ракурсі є дидактикопсихологічне забезпечення умов, сприятливих для такого виду та рівня навчальної діяльності студента.

Ece, як літературний жанр, фокусується на індивідуальних враженнях і міркуваннях автора 3 конкретної проблеми й неодмінно містить емоційно-ціннісну складову. Есеїстичному стилю притаманні образність, асоціативність мислення, особистісна орієнтованість трактування проблем, фактів, реалій. Тому в есе вітається вербалізація вражень, індивідуалізованих емоційних ставлень, суб'єктивних оцінок, міркувань автора, представлення власної позиції, автором своєї точки зору, особистої, тобто суб'єктивної оцінки предмета роздумів, що інтегрально диктує необхідність актуалізації творчого мислення автора, імпровізації, вільного стилю написання есе.

Метод есе $є$ затребуваним в ситуації, коли студент формує свій особистісно орієнтований освітній простір, у контексті якого визначається стратегія та програмується логіка й методика професійного становлення на основі “Я-концепції”, актуалізуючи суб’єктність позиції, творчий потенціал розвитку, що виступає неодмінними атрибутами компетентнісної моделі освіти. Зазначене $є$ актуальним і для використання есе як методу формування соціальної компетентності, соціальної рефлексії майбутнього вчителя.

У цьому плані важливою є позиція Інгрид Шун, яка пропонує релятивістський підхід до визначення соціальної компетентності, тобто розглядати поняття не як раз і назавжди усталене, а як сукупність співвідношень між індивідуальними характеристиками, соціальними вимогами та ситуативними характеристиками. Вона наполягає на тому, що соціальна компетентність змінюється протягом життя й залежить від розвитку в особистості таких якостей, як соціальна обізнаність, соціальні навички та самоусвідомлення. Адже із 2000 р. визначення поняття змінюється під впливом соціально-економічних змін і зростаючої глобалізації, що змушує дослідників усе частіше включати до поняття толерантність до етнічних та культурних відмінностей [7, 2-4].

Соціальні вимоги та ситуативні характеристики позначують особливість соціального середовища (як стихійного чи спеціально створеного), від яких буде залежати ефективність формування особистісних якостей, соціальної компетентності в цілому.

Соціо-дидактичне середовище (як навчальне середовище, яке формується у сприятливому соціальному контексті) функціонально спрямоване на забезпечення умов для самоактуалізації студента, реалізації потенціалу його інтелектуального, соціального розвитку у кожній конкретній навчальній ситуації, процесі професійного становлення загалом. Якісне соціокультурне середовище задає професійно, особистісно, соціально визначені стандарти освітньої діяльності, за якими студент має можливість в оптимальному для нього режимі взаємодіяти з усіма суб'єктами освітньої системи, навчального процесу, визначаючи свою індивідуальну траєкторію та програму професійного розвитку, формування професійно значущих компетентностей зокрема.

Соціо-дидактичний простір професійного розвитку вчителя в комплексі визначеного блоку компетентностей, як і соціокультурний простір вишу, повинен мати концепцію розвитку, науково обгрунтовану логіку програмування та змістового, технологічного забезпечення, що надасть змогу поетапно нарощувати його якісні показники, відслідковувати загальну ефективність процесу, i що най головніше - як викладачам, так і студентам стати реальними суб'єктами розвитку та оптимізації соціо-дидактичного середовища як психологічного контенту професійного навчання.

Лише так можна цілеспрямовано розвивати суб' єктність студента в оптимізації соціокультурного освітнього простору, інтеграції освітнього, соціального, життєвого просторів у системі його професійного становлення як педагога.

Трансформуючи зазначені вище теоретичні 


\section{РОЛЬСОЩІ-ДИДАКТИЧНОГОСЕРЕДОВИЩА У ПІДГОТОВЦІ МАЙБУТНІХ УЧИТЕЛІВ ДОНАПИСАННЯ ЕСЕ НАСОЦАЛЬНОЗНАЧУЩУ ТЕМАТИКУ}

засади на специфіку конкретного методу есе, який визначає формат творчої, особистісно орієнтованої навчальної діяльності, означимо головні позиції розвитку соціо-дидактичного середовища, які реалізуються через:

- спеціальне (кероване) формування системи довірливих взаємовідносин між викладачем і студентами, а також студентами між собою, психологічного прийняття один одного на основі розуміння, толерантності міжособистісних взаємовідносин, представлення та аналіз есе студентів на соціально-педагогічну проблематику за таких умов буде супроводжуватися інтересом до студента як особистості, його концепції та особливостей соціально-педагогічної спрямованості освітньої діяльності);

- формування атмосфери сприяння генеруванню оригінальних ідей, у тому числі таких, що виходять за межі традиційної логіки інтерпретації проблем, фактів, процесів, ефективність застосування методу есе буде безпосередньо залежати від того, наскільки на занятті підтримується інтерес до особистісних цінностей, роздумів, міркувань кожного студента, намагання зрозуміти його позицію, співвіднести зі своєю, отримати цінну навчальну інформацію);

- перманентну діагностику рівня соціодидактичного середовища за інтегральними показниками якості, позиціонування проблеми як предмета спільного інтересу, аналізу, долучення до колективної оптимізації ефективність використання методу есе за таких умов слугуватиме діагностичним параметром сприятливості соціо-дидактичного середовища, у якому відбувається навчальна діяльність);

- діагностики (самодіагностики) рівня середовища за критерієм сприятливості для самореалізації кожного студента, його орієнтованості на плідну творчу діяльність;

- звернення до методу есе як засобу сприяння розвитку соціально-рефлексійної компетентності майбутнього вчителя, інтегруючи навчальну інформацію з суб'єктивним (полісуб' єктним) досвідом іï трактування, збагачуючи їі та відсортовуючи студентом найбільш цінне, виходячи з власних потреб, пріоритетів розвитку;

- домінантності “внутрішнього управління”, “внутрішньої критики”, “внутрішнього оцінювання" в системі навчальної діяльності студента, відповідно - опосередкованого педагогічного управління викладачем творчою діяльністю, контролю за ії результативністю.

До чинників, що сприятливо впливають на формування соціодидактичного середовища під час написання есе відносимо наступні:
- чітка орієнтованість на стандарти компетентнісної освіти, оволодіння професією в широкому соціокультурному контексті, заохочення до пошуку адекватних форм і методів особистісної, професійної самореалізації студента, удосконалення системи суб' єкт-суб'єктних взаємовідносин як ії основи;

- високий рівень соціально-педагогічної компетентності викладачів, спонукання студентів до написання творчих робіт, виконання творчих проектів, здатність до ефективної організації творчої навчальної діяльності з адекватним інтелектуально-емоційним супроводом;

- культивування культури взаємовідносин, ставлення до студента як особистості, поважне зацікавлене ставлення до його думок, поглядів, оцінних суджень, творчих проектів;

- заохочення до сміливості самобутності суджень, оригінальності парадоксальності думок, сприйняття колективної творчої діяльності студента як сприятливих умов професійної самореалізації.

Висновок. Таким чином, роль соціодидактичного середовища у підготовці майбутніх учителів до написання есе на соціально значущу тематику складно переоцінити, оскільки воно пов'язане з формуванням сприятливих умов для творчої, особистісно орієнтованої навчальної діяльності студентів у процесі оволодіння професією, у тому числі формування соціальнопедагогічної та соціально-рефлексійної компетентностей.

Соціо-дидактичне середовище є складним психологічним, емоційно насиченим утворенням, яке реалізує об'єднувально-консолідувальну, мотиваційно-стимулюлювальну, емоційноенергетичну, регулювально-управлінську функції, спрямоване на розвиток творчої навчальної діяльності студентів, забезпечення створення визначеного комплексу дидактичних умов, адаптованих до особливостей реалізації методу есе, а відтак і розвитку соціальної компетентності майбутнього вчителя в системі особистісно орієнтованого професійного навчання.

\section{ЛІТЕРАТУРА}

1. Зеер Э.Ф. Психология профессий: учебн. пособие /Э.Ф. Зеер. [3-е изд.. перераб. и доп.]. М.: Академический Проект. Фонд “Мир”. 2005. $-336 \mathrm{c}$

2. Макагон О. Е. Середовище як об'єкт науково-педагогічного дослідження / Макагон О. Е. // Професійна підготовка та інноваційні процеси у навчально-виховних закладах: зб. наук. пр. - Х.: Стиль-издат, 2004. - С. 74-79. 
3. Орлова Л. Створення сприятливого освітнього середовища у вищому навчальному закладі // Витоки педагогічної майстерності: зб. наук. праць/Полтав. нац.пед. ун-тіменіВ.Г. Короленка. - Полтава, 2015. Випуск 16. - 332 с. - (Серія "Педагогічні науки").

4. Скидан С. О. Ергономічні основи навчального процесу у вищій школі: автореф. дис. ... д-ра пед. наук: спец. 13.00.01 “Теорія та історія педагогіки” / Скидан С. О., Національний педагогічний університет ім. М. П. Драгоманова. - К., 1999. $34 \mathrm{c}$.

5. Слободчиков В.И. Образовательная среда: реализация целей образования в пространстве культуры // Новые ценности образования: культурные модели школ. - Hrnnet Colledg. М.: Инноватор, 1997. - С. 177-184

6. Як написати успішне есе: Методичні рекомендації до написання есе / Укл. Шендеровський К.С. / Ін-т масової комунікації при КНУ імені Тараса Шевченка.- К., 2007. - 34 с.

7. Schoon Ingrid. Measuring social competencies // German Council for social and Economic Data (RatSWD). Working paper series №58. - 14 c., C. 2-4.

\section{REFERENCES}

1. Zeer, E. F. (2005). Psikhologiia professii [Psychology of vocations]. Moscow, Academic Project. "The World" Foundation., 336 p. [in Russian].

2. Makahon, O. E. (2004). Seredovyshche iak obiekt naukovo-pedahohichnoho doslidzhennia [The environment as an object of scientific and pedagogical research]. Professional training and innovative processes in educational institutions: the collection of scientific works., Kharkiv, Styl Publ., pp. 74-79. [in Ukrainian].

3. Orlova, L. (2015). Stvorennia spryiatlyvoho osvitnioho seredovyshcha u vyshchomu navchalnomu zakladi [The formation of a favorable educational environment in a higher educational institution]. Origins of pedagogical skill: the collection of scientific works. Poltava national V. H. Korolenko pedagogical university. Poltava, vol. 16, 332 p. [in Ukrainian].

4. Skydan, S. O. (1999). Erhonomichni osnovy navchalnoho protsesu u vushchii shkoli: avtoref [Ergonomic foundations of the educational process in the higher school]. Candidate's thesis. M.P. Drahomanov National Pedagogical University, Kyiv, 34 p. [in Ukrainian].

5. Slobodchykov, V. I. (1997). Obrazovatelnaia sreda: realizatsiia tselei obrazovaniiqa $\mathrm{v}$ prostranstve kultury [Educational environment: the realization of educational goals in the cultural space]. New values of education: cultural models of schools. Hrnnet Colledg., Moscow, Innovator Publ. pp. 177-184. [in Russian].

6. Shenderovskyi, K. S. (2007). Iak napysaty uspishne ese: metodychni rekomendatsii do napysannia ese [How to write a successful essay: Guidelines for writing essays]. Institute of mass communication at the Taras Shevchenko National University. Kyiv, 34 p. [in Ukrainian].

7. Schoon Ingrid. Measuring social competencies. German Council for Social and Economic Data (RatSWD). Working paper series No. 58. 14 p., pp. 2-4. [in English].

Стаття надійшла до редакції 18.06.2018

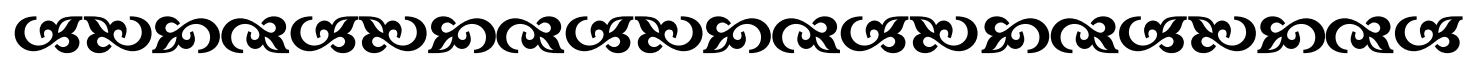

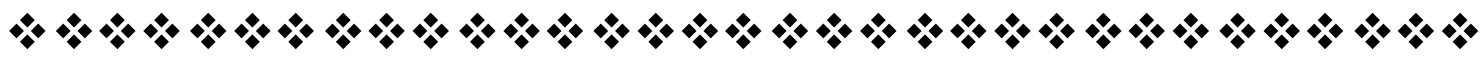

"Обдумуй по двічі і по тричі те, що спадає тобі на думку".

Феогнід

давнъогрецький поет

“Написане повинне бути легқе для читання і легковимовне, що одне і те ж”.

Apicmoтeль

давньогрецький ббілособ

“Dля того, щоб яка-небудь науқа зрушилася з місия, щоб розширення ї̈ стало здійснено, гіпотези необхідні так само, яксвідчення досвіду і спостереження".

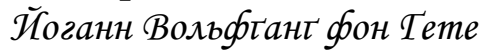
німеиький поет

\section{$\% * \% * \% \%$

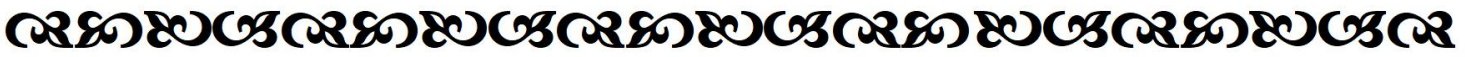

